\title{
Performance Assessment of Public Service Organisations in Shared Solid Waste Services: A case for Kampala Capital City Authority in Uganda
}

\author{
Nabukeera Madinah ${ }^{1}$, Ali Boerhannoeddin ${ }^{2}$ \& Raja Noriza Binti Raja Rriffin ${ }^{3}$ \\ ${ }^{1}$ Kyambogo University, Department of History and political science, Kampala, Uganda \\ ${ }^{2,3}$ University Malaya, Faculty of Economics and Administration Kuala Lumpur, Malaysia \\ Correspondence: Nabukeera Madinah, Kyambogo University, Department of History and political science, P.O.Box \\ 1, Kampala, Uganda. E-mail: nabmadinah@gmail.com/nabmadinah@siswa.um.edu.my
}

Received: May 28, $2014 \quad$ Accepted: June 16, $2014 \quad$ Online Published: June 18, 2014

doi:10.5430/wjss.v1n2p86 URL: http://dx.doi.org/10.5430/wjss.v1n2p86

\begin{abstract}
This study evaluates the efficiency Kampala Capital City Authority in municipal shared solid waste management in Uganda by using a framework of cost, quality and social welfare (CQS). However, this specific research only evaluates the efficiency component of divisions' performance and the two remaining units are out of scope of this research. Major basis used to gather facts was a survey. Three types of survey forms were used on three diverse selected target groups i.e., (i) residents; (ii) employees; (iii) divisions of KCCA were raised to gather relevant information. Outcomes revealed that in KCCA the rank in respect to efficiency, usage of capital is adequate and the objective is accomplished persuasively in an economic manner. Possibly, the outcomes will apply as suggestions for residents, KCCA divisions, strategy architects, planners, administrators while laying strategies and agendas in overhauling real competence of public service departments.
\end{abstract}

Keywords: Public sector, efficiency, Assessment, Municipal, solid waste management, KCCA, Uganda

\section{Introduction}

The need for financial sustainability and improved operational efficiency of the public sector coupled with political, social and economic changes have raised a need to adapt the best alternative methods of service delivery of public service departments. Societal and financial deviations i.e., increased requests by the voters for greater standards and a fiscal depression at the start of the 1990s have continuously controlled the state in which, uniquely, the responsibilities of the public authorities have turned out to be more difficult and changed on one hand whereas the, monetary capital is deteriorating at equal level (Steiner, 2003). The establishments of Uganda since 1980s have struggled to better efficiency of former Kampala City Council (herein after referred to as Kampala Capital City Authority - KCCA) for two decades. This is because (i) economic growth, social, cultural changes, constitutional and political development have changed; (ii) people are more informed and have a better understanding of their rights and freedoms due to availability of information revolution (Shah, 2003) and, hence can demand for quality public service, accountability and social equity; (iii) increased competition as a result of globalization forces (Flynn, 1995) has created gravity on PSOs to become more cost effective; (iv) ability to achieve objectives with limited resources and justify the expenditure (v) governments are key stakeholders and source of service delivery for the public good and therefore they become a subject of frequent debate and hence desire by scholars to investigate their performance; (vi) unification with many internal establishments (Osborne \& Brown, 2005a).

Failure of Local governments in Kampala to deliver services, resulted into a new KCCA Act where we witnessed partnership arrangements (city-sub county merger) under the current administration, which was set up after the approval of the KCCA Act 2010 and with the appointment of the current Executive Director as the chief executive of the Authority, the accounting officer and head of the public service in the Authority. The intention was to restructure, transform and reposition the Authority to deliver quality services to the people of Kampala.

Theorists argue that, scale leads to provision of experts, technical equipment hence efficiency (Andrews \& Boyne, 2009; Boyne, 1996a). Suggestion within public service indicates that 'administrative efficiency is higher in larger organizations' (Andrews \& Boyne, 2009b). It is argued that changing the structure of local government to 
recentralisation, can yield various benefits like; 'efficiency and equality effects on the operation of local authorities without diminishing the efficacy of local democracy, (B Dollery, Byrnes, Dollery, \& Robotti, 2008; Brian Dollery \& Crase, 2004; Brian Dollery, Crase, \& Johnson, 2006). Partnership with other public services departments propose that public - public partnerships are associated with 'collective service success, cost-effectiveness, and service equity' (Andrews \& Entwistle, 2010a).

The major aim of this research is to assess the degree of efficiency of different divisions of Kampala Capital City Authority a Public Service Organisation entrusted to deliver services to residents of Kampala City. There are five divisions i.e., Kampala Central Division (KCD), Nakawa Division (ND), Makindye Division (MD), Lubaga Division (RD) and Kawempe Division (KD). The study is arranged into five units. Next to this, is the review of literature on administrative efficiency, unit three debates the methods, unit four argues the analysis and last deliberates the conclusion.

\section{Administrative Efficiency (AE1)}

Information mutiny permitted citizenry has improved consciousness of human privileges. In support, (Huckfeldt, 1995) argued that, PSOs suffer growing burdens yet they produce significant productivity for the public. Currently Public Sector efficiency has become significant as governments are required to spend less for more and focus on performance measurement than in the past (Thiel \& Leeuw, 2002).

A number of scholars have argued, that partnership functioning can improve efficiency and organizational performance. They include among others; (Andrews \& Boyne, 2009c; Andrews \& Entwistle, 2010b; Boyne, 1996; Brian Dollery, Grant, \& Akimov, 2010; McQuaid \& Scherrer, 2010; Osborne \& Brown, 2005b; Sullivan \& Skelcher, 2002; Teisman \& Klijn, 2002).

The efficiency of public service organizations has been under a high level of inquiry in contemporary world for many years. Efficiency is doing things right. It deals with attaining the goals of the proposed action with least cost and period and through proper use of assets. Efficiency is executing responsibilities accompanied with minimum amount of misused effort (Jreisat, 1997). The same line of thinking can be linked to (Moharir, 1997) who argues that, efficiency involves acquiring the greatest output from the specific inputs. (Jackson, 1995) describes efficiency as a relation among outcomes and capital used in the production process. Hannington Emerson (in the beginning of the $21^{\text {st }}$ century) defined efficiency as a relationship between what is accomplished and what might be accomplished. Efficiency is concerned with both economic and technical aspects of the organization. This explains how much the system absorbed (cost) and how much of inputs emerges as the product (output). So it simply relates to how an organization converts inputs into outputs. Thus there must be no wastage of resources for an organization to be efficient. In local governments there is wastage since there is no competition and worry for takeover or merger in case of failure.

Quantifying inputs and outputs is one way of measuring efficiency and this is easy for profit generating organization (Moharir, 1997a). This is evident as money acts as a common denominator for measurement of both inputs and outputs and it also allows comparison. But this is not easy for public sector where there other factors involved which can't directly or indirectly be measured in financial expressions. In poor and under developed countries there is a cute situation of lack of capital in form of resources and citizens are disappointed with the nature of services delivery they receive from the districts. Efficiency qualifies as an important criteria of measuring shared services since it can improve public service delivery.

According to this belief first mentioned by (Wilson, 1987) and later by (Goodnow, 1900); political neutrality is supposed to guarantee efficiency and effectiveness. This argument was supported by (Gulick, 1937) as he proclaimed that efficiency is a number one on the administration value scale. An organization is efficient when its actions that argument the value of variables required for the performance necessarily reduces another. Efficiency through scientific management can be measured and improved by conducting scientific analysis aimed at the discovery of 'one best way' of carrying out each project. Public sector productivity is often viewed as measuring efficiency or effectiveness (output) of the productive effort (Luthuli, 1999) and the state and level at which given inputs are required to generate an output. Welfarism and efficiency of state machinery is also challenged when it comes to services. Competing perceptions of efficiency at different levels can mean that there is insufficient agreement on the process and implementation mechanisms. These disagreements among scholars have resulted into innovative ways of efficiency measurement. Measuring efficiency verifies considerably depending on what is intended to be measured i.e., components of efficiency in waste management differ from those of health depending on the model under study. Therefore, care should be taken by researchers to define more precisely, specify the procedure, application and 
indicate how the components will be measured thus providing alternative ways to measure efficiency hence contributing to the ongoing debt.

\subsection{Measuring Efficiency in KCCA Divisions}

In KCCA efficiency refers; to exploiting the use of available resources. Shared service partnerships are likely to reduce on the amount of time taken to deliver the services and shared service partnerships have enabled divisions to carry out their respective policies and plans more efficiently. It is a mechanism to improve service delivery (Andrews \& Entwistle, 2010b). (Teisman \& Klijn, 2002) affirm that partnership working 'allows state fresh correctness, (Ashkenas, Ulrich, Jick, \& Kerr, 1995), while greater efficiency should arise from promising greater flexibility to divert 'choices, capability, honors and activities in places where they are most required'.

According to (McQuaid \& Scherrer, 2010b), sharing knowledge, expertise and resources, pooling of resources to 'increase the total level of resources brought to bear on problems', improving efficiency and removing duplication. (Andrews \& Boyne, 2009d; Boyne, 1996c), argue that, sharing leads provision of experts, technical equipment hence efficiency and continued to argue that, due to the concentration, the equipment can be procured at lower costs hence group buys and then the equipment can be shared by all the organizations in the partnership or the large organization. The concept can be applied on solid waste management in KCCA. Nevertheless, if KCCA can show that there are increased tons of garbage can be collected using same allocated annual budget, then a high efficiency in such a base-case-scenario can be justified. The functioning pointers of efficiency have been ranked centered on (i) Exploiting the use of available resources (ii) amount of time taken to deliver the services and (iii) enabled divisions to carry out their respective policies and plans more efficiently.

\subsubsection{Cost Measures}

In case of KCCA divisions, efficiency represents the cost per unit of output (Boyne, 2002). How much resources are needed to collect garbage from the city? In quantification, some pointers were assigned:

- KCCA solid waste budget

- Cost per ton of collected garbage. The cost component with the use of formula can be measured using output and input.

\section{Aggregated cost of solid waste budget annually}

Aggregated number of tons of garbage collected annually

This provides a typical cost for each ton. Through linking the current cost and past year's, the amount of growth or reduction in cost for each ton specifies the efficiency levels of KCCA. Furthermore, to measure efficiency of $\mathrm{KCCA}$, the cost for each ton in each division under KCCA could be compared with the cost per ton among the different divisions and this applies to Uganda were solid waste is still at a traditional stage.

- Overall expenses on garbage collection as related to overall expenses on employees in public service. The proportion indicates government's expenditure on garbage collection.

- Number of tons dumped at the landfill by KCCA refuse trucks or costs versus the number of times each refuse truck dumps garbage at the landfill. The results will specify the effectiveness and efficiency KCCA in utilizing the available resources to managing garbage collection.

\subsubsection{Production Quantification}

Production pointers relate to the achievement from the input (Moharir, 1997a) i.e., reduced or no garbage in the skips and streets of Kampala roads. An evaluation of the work not outcome, that is to say that, it responds to what was done and how. The pointers that will be used to evaluate the output are; sanitation of the city as result of improved waste time collection.

Table 1. Indicators of efficiency for Shared SWM KCCA

\begin{tabular}{lll}
\hline Criteria & Performance indicators & Target \\
\hline Efficiency & (i) $\quad \begin{array}{l}\text { Cost } \\
\text { Exploiting the use of available resources }\end{array}$ & $\begin{array}{l}\text { Directors KCCA \& senior } \\
\text { officials. }\end{array}$ \\
$\begin{array}{l}\text { Shared service partnerships are likely to reduce on the } \\
\text { amount of time taken to deliver the services. }\end{array}$ & $\begin{array}{l}\text { Employees of KCCA in public } \\
\text { health department } \\
\text { Shared service partnerships have enabled divisions to } \\
\text { carry out their respective policies and plans more } \\
\text { efficiently. }\end{array}$
\end{tabular}

As shown table 1, indicates indicators of efficiency Source: Researcher 


\section{Impact Based Pictures Showing KCCA Efficiency Improvement at Old Kampala}
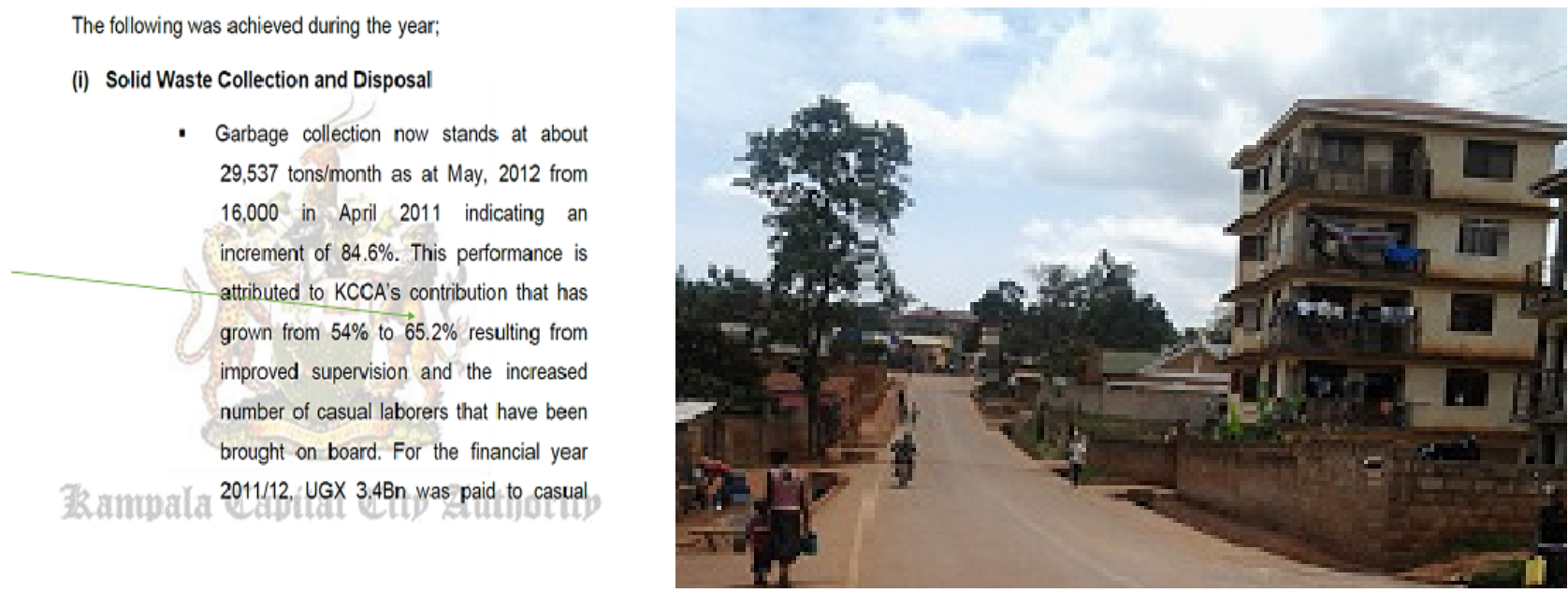

\section{Methodology}

Shared solid waste management service in Public Sector in Uganda is a portion of the doctoral thesis that measures the assessment of its implementation. The study uses a framework of cost, social welfare social and quality (CSQ) further broken down into; social welfare, standards, economies of scale, efficiency, effectiveness, equity, cost, quality and quantity (SSEEEECQQ). Therein, specifically the study, is a paired perspective though; it applies to efficiency aspect of Organizational Performance.

\subsection{Population Defined and Selection Technique}

In this case study KCCA an organization in Uganda whose five divisions were considered. Main data for this research i.e., answers were acquired from three responders i.e., (a) former and current employees of KCC i.e., senior and public health department employees of KCCA including politically elected leader; (b) residents and (c) KCCA divisions were used to collect objective data. The process of selection for the three intended clusters is described below;

\subsubsection{Sampling Method}

Cluster sampling method was applied for this study because the KCCA survey area was too large. KCCA is divided into 5 strata (Divisions), and a survey performed in each stratum (30 clusters, 20 voting age persons in each cluster). It was therefore a multi-stage sampling method i.e. completed in 2 stages:

The 1st stage (random selection of clusters) is where the entire population of Kampala was divided into small distinct geographic areas, such as parishes and an approximate size of the population for each "parish" was found. At this stage, the primary sampling unit (PSU) is the parish. Afterwards, clusters were assigned randomly to parishes. The 2nd stage (random selection of voting age persons within clusters) was chosen randomly within each cluster using systematic random sampling.

Table 2. Cluster selection by PPS

\begin{tabular}{|c|c|c|c|c|c|}
\hline Division & $\begin{array}{l}\text { Estimated total } \\
\text { Population }\end{array}$ & $\begin{array}{l}\text { Cumulative } \\
\text { population }\end{array}$ & $\begin{array}{l}\mathbf{N}^{0} \\
\text { Allocated }\end{array}$ & $\begin{array}{l}\text { Clusters } \\
\text { (Parishes) }\end{array}$ & $\begin{array}{l}\text { Sample } \\
\text { units }\end{array}$ \\
\hline Central & 176,344 & 176,344 & $1-176344$ & $1,2,3$ & 72 \\
\hline Kawempe & 554,225 & 730,569 & $176345-730569$ & $4,5,6,7,8,9$ & 145 \\
\hline Makindye & 654,993 & $1,385,563$ & $730570-1385563$ & $10,11,12,13$, & 193 \\
\hline Nakawa & 503,841 & $1,889,404$ & 1385564-1889404 & $22,23,20,21$, & 144 \\
\hline Rubaga & 629,801 & $2,519,205$ & $1889405-2519205$ & $\begin{array}{l}24,25,26,27, \\
28,29,30\end{array}$ & 169 \\
\hline Total & $2,519,205$ & & & 30 & 723 \\
\hline
\end{tabular}


4.1.2 Former and Current Employees, Senior and Public Health Department Employees of KCCA Including Politically Elected Leader

For this study, all employees who worked in Kampala City Council (KCC herein after referred to as Kampala Capital City Authority - KCCA), during the period 2005-2013, represented the case. The catalog for earlier employees was unavailable because after the transformation from KCC to KCCA all the old information was destroyed it was total transformations that involved sucking many employees and replacement of new ones. According to KCCA employment record, although they plan to work with 1150 employees most positions are still vacant. The operational staffs in public health department solid waste section are mostly casual workers and since KCCA is still working with few contract full time staff, 302 questionnaires were distributed specifically 47 to senior staff and 155 for the five divisions and 100 to former employees and due to difficult in identifying former employees, snow ball sampling was used while distributing the 100 questionnaires. A total of 127 responses (17.57) were received.

\subsubsection{Residents}

The residents in five divisions include the business community, town dwellers, traders, market vendors, and their representatives like KACITA. 563 questionnaires dispersed for this category and a return 446 questionnaires was received a percentage of (61.69).

\subsubsection{KCCA Divisions}

All the five divisions that under KCCA were selected for this research. The total populace was preserved as a sample since all information is found National Bureau of Statistics. This explains why five forms were administered with a return of (100) percent return.

\subsection{Data Sources}

The study data was gathered using secondary and primary bases. These were accompanied by semi- structured and unstructured interview with previous and current employees. Document sources i.e., reports, minutes of meetings, journals, books rules and regulations, financial statements, circulars, and official documents were examined. Necessary data concerning organizational efficiency was evaluated and for survey data, the case comprised of KCCA employees and residents.

\subsection{Collection of Data}

The practical work for gathering information for this research took place in Uganda. A "mixed" method to field work by use of dissimilar approaches i.e., (a) questionnaire; and, (b) interviews to gather data as follows:

\subsubsection{Survey Form}

Survey form 1 (See Appendix A1) is in pursuit for responses from KCCA senior employees and employees in public health department employees of KCCA at the divisions. It is divided into four sections. Section (a) requires the background information section (b) seeks the respondents' views on solid waste service management in KCCA. Section (c) seeks respondents' views on service delivery in terms solid waste services management under shared services while section (d) seeks respondents' views in relation to (CQS) cost, quality and social welfare of solid waste service delivery of Kampala City Capital Authority.

Questionnaire II (See Appendix A2) is in pursuit for responses from residents' .i.e., town dwellers, traders, market vendors, business community in the city and their representatives like Kampala City Traders Association (KACITA). It is divided into four sections. Section (a) requires the background information and section (b) seeks the respondents' views on solid waste service management in KCCA. Section (c) seeks respondents' views on service delivery in terms solid waste services management under shared services and section (d) seeks respondents' views in relation to (CQS) cost, quality and social welfare of solid waste service delivery of Kampala City Capital Authority.

The questions in questionnaires $\mathrm{A} 1$ and $\mathrm{A} 2$ part $\mathrm{C}$ and $\mathrm{D}$ are in mode of a psychometric scale. The scale describes formats of variation or achievement ranges i.e., strongly disagree (1) disagree (2), neutral (3), agree (4) to strongly agree (5) and strongly disagree. (1), disagree (2), somehow disagree (3), slightly disagree (4), neutral (5), slightly agree (6) somehow agree (7) quite agree (8), agree (9) to strongly agree (10) respectively. The three questionnaires were distributed by the researcher. 
Table 3. Responder Ratio

\begin{tabular}{llll}
\hline $\begin{array}{l}\text { Questionnaire } \\
\text { Used }\end{array}$ & Respondents/Target group & $\begin{array}{l}\text { Number of } \\
\text { responses }\end{array}$ & $\begin{array}{l}\text { Percentage } \\
\text { responses }\end{array}$ \\
\hline I (A1) & $\begin{array}{l}\text { KCCA senior employees and preventive health in Public } \\
\text { health department employees current and former }\end{array}$ & 127 \\
II (A2) & Residents in five divisions of KCCA & 446 & 61.69 \\
III & Divisions & 5 & 100 \\
\hline
\end{tabular}

As shown table 3, indicates Respondents Ratio

Source: Researcher

\subsection{2}

For this research, the main tool for information gathering was a survey. Nevertheless, unstructured and semi-structured interviews with employees were as well carried out in backing up the data collected using questionnaires. A question guide was provided from questions in survey form I and II throughout interview sessions for responses on the operations of KCCA. Every interview session during field work lasted about thirty and forty-five minutes where interviewees explained their lived experiences with KCCA and KCC's performance. The interviewees were mainly operational staff in public health department in senior, middle and lower positions. Two focuses during the interview session were also conducted in relation to performance and the sessions acted as a moment of truth since employees were freely airing out their views saw it as a right chance at the right time and conveyed exhaustive information related to the questionnaires.

\subsection{Employed Methods}

The section explains approaches used during data analysis of collected data. The collected data that was arranged into Microsoft Excel for the first file, was checked and edited, in layers before it was explored through Statistical Package for Social Sciences (SPSS, version 16.0) for Windows for analysis. Diverse types of analysis were used i.e., (a) descriptive for background information; (b) validity and reliability; (c) factor analysis was carried out to obtain element components. Means of the factor elements to support in evaluating success of KCCA divisions; (d) means of diverse subdivision- scales of survey forms; and (e) independent sample test and one way inquiry (ANOVA) were explored to diverse subdivision-scales of survey forms to test numerous demographic clusters mean variances for significance.

\section{(a) Investigating the Performance in Efficiency Dimensions of OP}

The dimension of efficiency mechanisms;

Primarily, total indices of CQS later SSEEEECQQ were attained by prefixing SSEEEECQQ indices of all the five divisions of KCCA. The particulars of the computation of performance indices of the efficiency capability can be noticed below the subtitle of ranks of different divisions of KCCA. Since, a 10 point scale rating from 1-10 was employed for this research, consequently, 5.0 was earmarked as neutral as it is the indifferent fulfillment point of responders.

Furthermore, final indices of CQS later (SSEEEECQQ), marked factor fixings and their mean scores of survey form I and II obtained from factor analysis. The lower or higher mean score, comparing with the yardstick, will determine the accomplishment of KCCA divisions in every aspect. To assess the mean scores of a representative sample to an identified value, One-sample test was performed for this aim, since it is unknown but assumed mean. If the value is less than .05 for the two-tail significance, then this implies that the difference among the mean values is significant.

(b) KCCA divisions Ranking

In order to ascertain the order rank of accomplishment of five divisions of KCCA, accomplishment indices were determined. This model was adapted from (Waheed, Mansor, \& Ismail, 2011), who also previously adapted the formula from (Kuppusamy, Sidin, Sambasivan, \& Noor, 2006) which he applied while assessing accomplishments of Local governments in Kuala Lumpur.

$$
\begin{aligned}
& \mathrm{PKD}=\underline{\mathrm{W}}_{1}\left(\mathrm{C}_{1}\right)+\mathrm{W}_{2}\left(\mathrm{E}_{2}\right)+\mathrm{W}_{\underline{3}}\left(\mathrm{E}_{3}\right)+\mathrm{W}_{4}\left(\mathrm{E}_{4}\right)+\mathrm{W}_{\underline{5}}(\mathrm{Q})+\mathrm{W}_{\underline{6}}(\mathrm{Q})+\mathrm{W}_{7}(\mathrm{~S})+\mathrm{W}_{\underline{8}}(\mathrm{~S})+\mathrm{W}_{9}(\mathrm{E}) \\
& \mathrm{W}_{1}+\mathrm{W}_{2}+\mathrm{W}_{3}+\mathrm{W}_{4}+\mathrm{W}_{5}+\mathrm{W}_{6}+\mathrm{W}_{7}+\mathrm{W}_{8}+\mathrm{W}_{9}
\end{aligned}
$$


Where PKD represents performance of KCCA divisions, centered on the total average scores for means of the nine components of performance achieved from the weights determined by different experts;

$\mathrm{C}=$ Mean scores of diverse subdivision-scales relating to cost component in shared services.(questionnaire I and II)

$\mathrm{E}=$ Mean scores of diverse subdivision-scales relating to effectiveness component in shared services.(questionnaire I and II)

$\mathrm{E}=$ Mean scores of diverse subdivision-scales relating to efficiency component in shared services.(questionnaire I and II)

$E=$ Mean scores of diverse subdivision-scales relating to economies of scale component in shared services.(questionnaire I and II)

$\mathrm{Q}=$ Mean scores of diverse subdivision-scales relating to quality component in shared services.(questionnaire I and II)

$\mathrm{Q}=$ Mean scores of diverse subdivision-scales relating to quantity component in shared services.(questionnaire I and II)

$\mathrm{S}=$ Mean scores of diverse subdivision-scales relating to standardization component in shared services.(questionnaire I and II)

$\mathrm{S}=$ Mean scores of diverse subdivision-scales relating to social welfare component in shared services.(questionnaire I and II)

$\mathrm{E}=$ Mean scores of diverse subdivision-scales relating to equity component in shared services.(questionnaire I and II) and,

$\mathrm{W}_{1}+\mathrm{W}_{2}+\mathrm{W}_{3}+\mathrm{W}_{4}+\mathrm{W}_{5}+\mathrm{W}_{6}+\mathrm{W}_{7}+\mathrm{W}_{8}+\mathrm{W}_{9,-a r e}$ weights applied on nine components of performance i.e., cost, economies of scale, efficiency, effectiveness, quality, quantity, standardization, social welfare and equity (SSEEEECQQ) and decided by the expert interviews in diverse fields. Centered on the average feedback from seven professionals, the subsequent weights were allotted to nine components of performance.

$$
\mathrm{W}_{1}=0.12 ; \mathrm{W}_{2}=0.12 ; \mathrm{W}_{3}=0.20 ; \mathrm{W}_{4}=0.15 ; \mathrm{W}_{5}=0.10 ; \mathrm{W}_{6}=0.10 ; \mathrm{W}_{7}=0.06+\mathrm{W}_{8}=0.08 ; \mathrm{W}_{9}=0.07
$$

The collection of nine indices used for performance centered on average mean scores of nine components i.e., social welfare, standards, economies of scale, efficiency, effectiveness, equity, cost, quality and quantity (SSEEEECQQ), were fixed for every division independently.

The third performance index embed the effectiveness (E3) component which contains average mean scores of diverse elements linking to subdivision-scales of shared service effectiveness of questionnaire I and II.

The second E is efficiency (E2) performance index which embed average mean scores of elements under efficiency derived from the subdivision-scales cost estimates, output estimates and policies and plans. To calculate indices for efficiency of KCCA independently, target records from (Questionnaire III) were recorded for each division after being acquired and transformed into an index for every element then calculated by actual values that are formerly standardized to formulate indices ranging from 1-10. The formula and procedure below is employed for adapting aimed data to form an index for this research:

\section{Efficiency Index $=\underline{\text { Minimum pointer amongst all divisions }}$}

Maximum pointer amongst all divisions

Therefore the index in range from $0-1$ is attained, and then standardized to formulate an index range 1 to 10 through multiplication with 10. Likewise, to calculate the efficiency index of cost in terms of average per division in KCCA, information concerning average cost in each independent variable was itemized and computed based on the figures got from the divisions. (See Appendix A3) 
Table 4. Average Cost Efficiency Index

\begin{tabular}{llllll}
\hline Cost indicator & Kampala central & Lubaga & Makindye & Kawempe & Nakawa \\
\hline $\begin{array}{l}\text { Average cost on } \\
\text { health }\end{array}$ & $\$ 156425_{\text {(Maximum) }}$ & $\$ 118179$ & $\$ 114447$ & $\$ 120988$ & $\$ 113701$ (Minimum) \\
All indices & 1 & 1.51 & 1.47 & & \\
Over all indices & 10 & 7.55 & 7.31 & 7.73 & 7.46 \\
$\begin{array}{l}\text { Efficiency } \\
\text { index (reverse) }\end{array}$ & 1 & 5 & 6 & 3 & 7 \\
\hline
\end{tabular}

As shown table 4, indicates cost efficiency

Source: Researcher

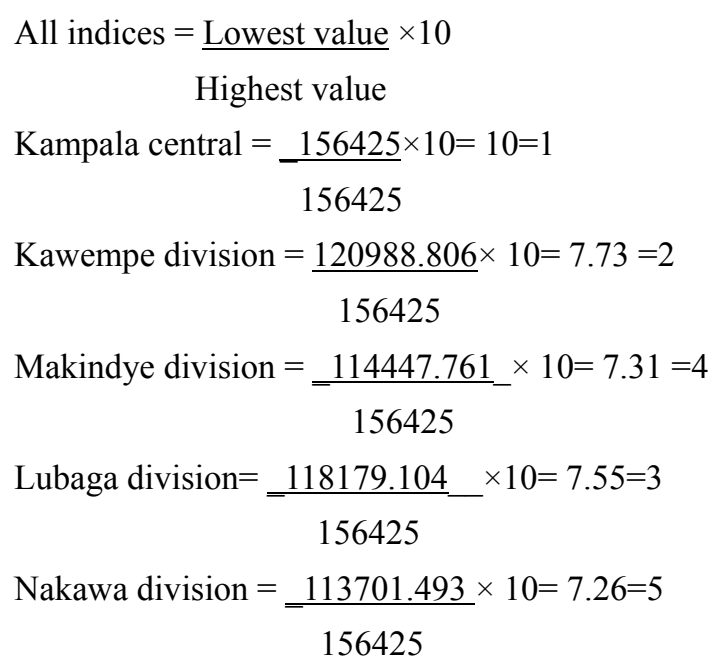

A similar formulation and technique was used to ascertain the efficiency indices for every component (See Apendeix 1A). For the rest of eight performance indices (i.e., social welfare, standards, economies of scale, equity, cost, quality, effectiveness and quantity dimensions), the average mean scores of components regarding subdivision-scales 'social welfare', 'standards', 'economies of scale', ' equity', 'cost', 'quality', 'effectiveness' and 'quantity' in survey form I and II, were used to calculate average mean scores and index of components concerning subdivision-scales 'social welfare', 'standards', 'economies of scale', ' equity', 'cost', 'quality' and 'quantity' of survey form I and II to calculate their indices separately.

The nine presented indices of performance using SSEEEECQQ are basically aggregated with an allocated estimated cluster weights to compute the compound performance index of all divisions under KCCA. The peak index and mean score implies that the performance associated to that division is considered outstanding compared to lesser scores.

\section{Results Analysis}

\subsection{General Efficiency}

In terms of measuring efficiency of KCCA divisions, the general efficiency index (4.980) was attained by totaling efficiency indices for the five divisions under KCCA in the Table 4, which nearly equates to (5.0). Results clearly indicate that the index in terms of efficiency in KCCA is acceptable since it is almost equivalent to the set standard (5.0) on the ten-opinion scale and distant from ideal. This proposes that there are grey areas that need enhancement specifically in resource utilization for efficiency to reach optimal level. 
Table 5. The general performance of KCCA divisions in all Dimension

\begin{tabular}{|c|c|c|c|c|c|c|c|c|c|c|}
\hline 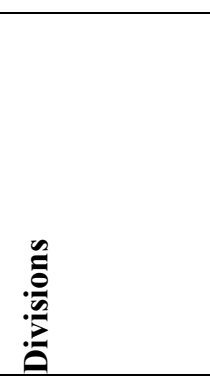 & $\overrightarrow{\tilde{\theta}}$ & 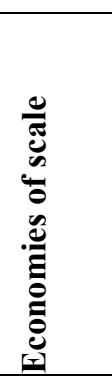 & 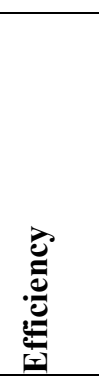 & 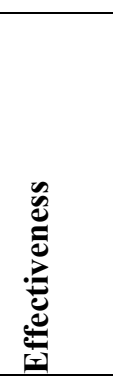 & $\frac{\vec{E}}{\tilde{E}}$ & 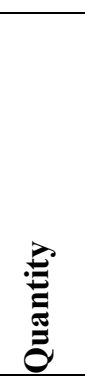 & 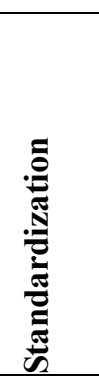 & 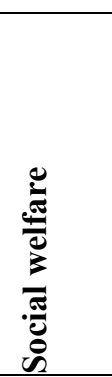 & 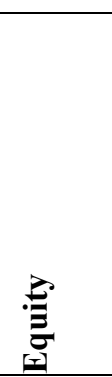 & 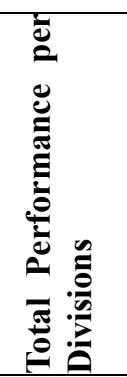 \\
\hline Central & 4.613 & 5.56 & 4.96 & 7.805 & 3.062 & 1.15 & 1.555 & 2.569 & 1.674 & 6.36906 \\
\hline Lubaga & 4.813 & 5.425 & 6.31 & 8.132 & 3.191 & 1.12 & 1.55 & 2.534 & 1.786 & 6.50182 \\
\hline Kawempe & 4.47 & 5.345 & 3.858 & 7.893 & 3.113 & 1.15 & 1.49 & 2.57 & 1.716 & 6.32064 \\
\hline Makindye & 4.634 & 5.52 & 3.856 & 7.886 & 2.891 & 1.14 & 1.608 & 2.571 & 1.693 & 6.36028 \\
\hline Nakawa & 4.51 & 5.576 & 5.92 & 7.887 & 2.947 & 1.19 & 1.602 & 2.608 & 1.719 & 6.3849 \\
\hline $\begin{array}{l}\text { Overall } \\
\text { performance } \\
\text { per variable }\end{array}$ & 4.606 & 5.4852 & 4.980 & 7.9206 & 3.0408 & 1.15 & 1.561 & 2.5704 & 1.7176 & 6.387 \\
\hline
\end{tabular}

As shown table 5, indicates general performance of divisions

Source: Researcher

\subsection{KCCA Perception on Efficiency}

In Computing efficiency, objective information was acquired from the archives of KCCA, standardized and transformed into an index, extending from 1-10. The three pointers i.e., (i) exploiting the use of available resources; (ii) amount of time taken to deliver the services; and (iii) enable divisions to carry out their respective policies and plans more efficiently were labeled and employed as a computation of efficiency for KCCA divisions in shared solid waste management. The investigation of efficiency elements from survey form I and II also mean scores for all elements is computed and outlined Table 5.

(i) Measuring cost

Measuring cost, is a combination of output and input, i.e., amount of capital injected to collect garbage per year as specified in Section3. The entire cost contains; maintenance of refuse trucks, fuel and lubricants for refuse trucks, allowances of casual laborers, maintenance of landfill, cleaning tools, protective wear, litter bins and salary of casual workers. After analyzing the cost means (Table5), it turned out to be that element score means are slightly lower than the yardstick (4.606) i.e., (5.0) (this is the standard on a ten- opinion scale). This implies that sharing services has not necessarily reduced the costs of equipments used in KCCA. Nevertheless, amongst the five divisions, Nakawa appears to be better in efficiency as it takes the minimum average cost per ton of garbage and Kampala takes the maximum average cost per ton as shown in table4 and table 5.

Table 6. Scores for the means of Subdivision-Scale 'efficiency' of survey form I and II (KCCA Divisions)

\begin{tabular}{lllll}
\hline Survey form & Measurement & Components & No of items & Mean Scores \\
\hline & $\begin{array}{l}\text { 1. Exploiting the use of available } \\
\text { resources }\end{array}$ & 6.62 \\
$\begin{array}{l}\text { 2. amount of time taken to } 5 \\
\text { deliver the services } \\
\text { Questionnaire I and II Efficiency } \\
\text { (KCCA Divisions) } \\
\text { respective policies and plans }\end{array}$ & 7.34 \\
\hline Total Mean Score & & 15 & 5.44 \\
\hline
\end{tabular}

As shown table 6, indicates Subdivision-scales of efficiency

Source: Researcher 
(ii) Amount of time taken to deliver services

The other three components to assess efficiency of KCCA divisions are output events. After observing them, we detected that, from the table 6 it is clear that output components mean scores of time taken 7.34, exploiting usage of resources 6.62 and policies and plans mean scores of 5.44 are all higher than the standard 5.0, which implies that the KCCA division's efficiency in terms of productivity i.e., time taken to collect garbage, exploitation of resources and implementation of policies the average mean scores is 6.47 recommending that performance is adequate since their mean score is higher than the identified standards i.e., 5.0.

The sum of mean score (6.47) of subdivision-scale efficiency is expressively greater than the identified standard. It implies that the general efficiency of KCCA divisions is rationally acceptable. Though, there seem to be many aspects that still need to be improved so that efficiency performance gets to optimal level. KCCA has been in existence for three years and efficiency in garbage collection has improved from $45 \%$ to $55 \%$ (Waste, 2011) this could be as a result of change of management in the city and enhancing new work methods like shared services since their primary aim is to improve efficiency in service delivery.

Through observation, there were no new refuse trucks in KCCA at the time of data collection and this may imply that the prior administrators under-utilized the available refuse trucks which led to accumulation of garbage backlogs in the city for many years hence poor performance. It has also been observed that sharing solid waste management services among divisions where there is a centralized purchasing system has enabled a strong bargaining power but operational costs are still high. This may imply that divisions working together through sharing have enabled the divisions to address complex garbage collection challenges in Kampala. Hence there is improved sanitation but has not necessarily reduced the costs of equipments. Documents also revealed that, the employees are highly motivated to perform their job an indication of good management practices that should be copied across all public sector organizations in Uganda.

Findings of the study indicate that, the overall performance in terms of efficiency at KCCA is satisfactory and performance tasks are done in a reasonably economic way in terms of Exploiting the use of available resources, amount of time taken to deliver the services and enabled divisions to carry out their respective policies and plans more efficiently. This may imply that sharing services in KCCA has not really impacted on costs reduction (see table: 5) but has influenced the implementation of KCC garbage ordinance hence the findings are in line with past studies and theoretical foundation of shared services (Pike, 2012).

\subsection{Positioning of KCCA Divisions}

The aim of this section is to position the divisions of in KCCA by instituting their indices in terms of performance. Performance indices of the divisions are computed through average mean scores of diverse subdivision-scales of survey form I and II. The details of the means used as data can be seen in (Appendix A4)

Creating an order rank for performance of KCCA divisions, the subsequent model was considered, as adapted from (Waheed et al., 2011), who also previously adapted the formula from (Kuppusamy et al., 2006) which he applied while assessing accomplishments of Local governments in Kuala Lumpur.

$$
\begin{aligned}
& \mathrm{PKD}=\underline{\mathrm{W}}_{1}\left(\mathrm{C}_{1}\right)+\mathrm{W}_{\underline{\underline{2}}}\left(\mathrm{E}_{\underline{2}}\right)+\mathrm{W}_{\underline{3}}\left(\mathrm{E}_{\underline{3}}\right)+\mathrm{W}_{\underline{4}}\left(\mathrm{E}_{4}\right)+\mathrm{W}_{\underline{5}}(\mathrm{Q})+\mathrm{W}_{\underline{6}}(\mathrm{Q})+\mathrm{W}_{\underline{7}}(\mathrm{~S})+\mathrm{W}_{\underline{8}}(\mathrm{~S})+\mathrm{W}_{\underline{9}}(\mathrm{E}) \\
& \mathrm{W}_{1}+\mathrm{W}_{2}+\mathrm{W}_{3}+\mathrm{W}_{4}+\mathrm{W}_{5}+\mathrm{W}_{6}+\mathrm{W}_{7}+\mathrm{W}_{8}+\mathrm{W}_{9}
\end{aligned}
$$

These nine indices for performance of SSEEEECQQ are merely totaled with an allocated cluster of weights to compute the compound index of performance for KCCA divisions. The maximum index implies that the mean performance associated to that particular division is considered exceptional to the rest. Table 7 shows the computed indices of KCCA divisions in terms of performance:

Table 7 indicates the detailed computation of indices. The outcomes point to Lubaga division, sustained the best ranking amongst all divisions of KCCA followed closely by Nakawa. Kampala Central division and Makindye acquired third and fourth position respectively, retaining Kawempe in the last position. 
Table 7. The performance Indices of Divisions of KCCA and their Rank Order

\begin{tabular}{|c|c|c|c|c|c|c|c|c|c|c|c|c|}
\hline$\stackrel{0}{0}$ & $\overrightarrow{\tilde{\theta}}$ & 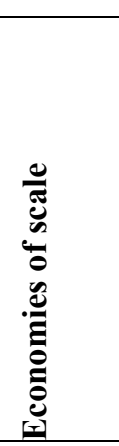 & 总 & 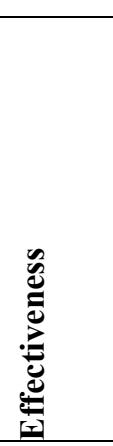 & 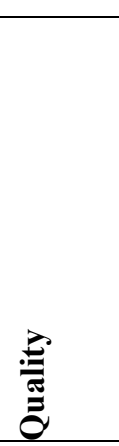 & 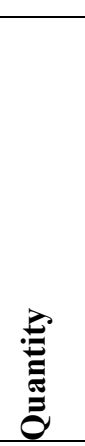 & 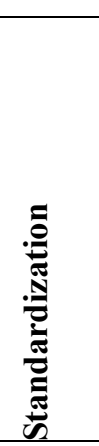 & 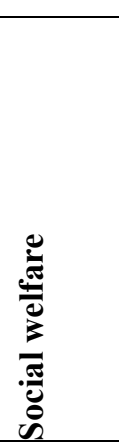 & $\underset{\Xi}{\stackrel{\Xi}{\Xi}}$ & 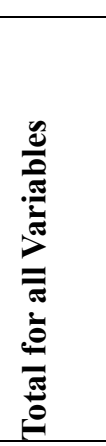 & 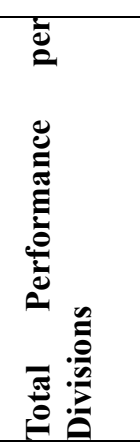 & 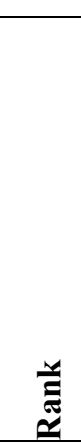 \\
\hline Central & 4.613 & 5.56 & 4.96 & 7.805 & 3.062 & 1.15 & 1.555 & 2.569 & 1.674 & 31.85 & 6.36906 & 3 \\
\hline Lubaga & 4.813 & 5.425 & 6.31 & 8.132 & 3.191 & 1.12 & 1.55 & 2.534 & 1.786 & 32.51 & 6.50182 & 1 \\
\hline Kawempe & 4.47 & 5.345 & 3.858 & 7.893 & 3.113 & 1.15 & 1.49 & 2.57 & 1.716 & 31.6 & 6.32064 & 5 \\
\hline Makindye & 4.634 & 5.52 & 3.856 & 7.886 & 2.891 & 1.14 & 1.608 & 2.571 & 1.693 & 31.8 & 6.36028 & 4 \\
\hline Nakawa & 4.51 & 5.576 & 5.92 & 7.887 & 2.947 & 1.19 & 1.602 & 2.608 & 1.719 & 31.92 & 6.3849 & 2 \\
\hline $\begin{array}{l}\text { Overall } \\
\text { performance } \\
\text { per variable }\end{array}$ & 4.606 & 5.4852 & 4.980 & 7.9206 & 3.0408 & 1.15 & 1.561 & 2.5704 & 1.7176 & 6.387 & 4.606 & \\
\hline
\end{tabular}

As shown table7, indicates rank order

Source: Researcher

\section{Conclusion}

In general, the efficiency indices in KCCA divisions is satisfactory because the results are almost equal to the standard (5.0) on a ten-opinion scale and but not close to ideal. The recommendation is for KCCA is to improve in the scope of efficiency i.e., through collecting garbage on time, utilization of available resources and proper implementation of the garbage ordinance 2000. The scores for the means of the three elements i.e., output determinants are above the standard (5.0) and the total mean score 6.47 of subdivision-scales efficiency is on cutting age of the standard mark (5.0), this may imply that KCCA should put a lot of emphasis on implementation of the garbage ordinance 2000 since this will result in reduction in indiscriminate waste disposal behaviors and boost their income and expenditure. However cost index indicate that that KCCA is not cost-effective in their operation an area that needs to be addressed in order to achieve their objective of an enterprising government. The foregoing investigation reflects the position at KCCA in terms of efficiency and resource utilization is generally optimal since they are executing tasks economically.

There is also over utilization of resources which is also dangerous in the long run. Therefore KCCA should allocate funds to avail more resources in garbage collection. Interviews with solid waste employees, suggest that efficiency in solid waste management infers to highest level of collection and minimum spending in relation to effort, investment and time.

Inappropriately, what happens practically is different. Obtainable validations from the report indicate that there was boost in the budget by $100 \%$ to ensure the beautification and sanitation of the city but quality is still low. This may be because government has taken over the management of the city through forced amalgamations of the five divisions and as a result there is willingness to support service delivery since it was envisioned that the changes of management and structures will results into improved service delivery to the much needed population.

It should be noted however that, shared services might deprive the local people of their democracy after amalgamation of all the divisions and changing to a centralized system of administration. Also there is a potential danger of failure to optimize skills of some employees and other resources like time which is disadvantageous to employees in the long run. Indeed shared services have the potential to share resources, consolidate technology and yield economies of scale. However, there is likely to be too much bureaucracy since the five divisions were merged with one budget. This giant is likely to establish processes in the long run that may delay service delivery in favor of control and power.

This model has proved to improve service delivery in KCCA and the current methods in the up districts in Uganda 
should be investigated if there are not very effective and efficiency, then the shared service model should be replicated in all big municipalities in order to give government correctness and improve its accountability and royalty to the people. Care must be taken when implementing services since its success highly depends on how well the implementation process was carried out. All stakeholders should be involved, there should be an agreed shared vision among the partners and most importantly trust should be enhanced as it is a key success factor for shared services to succeed.

The model is still new in KCCA further research needs to be done in future to establish if there is an improvement in quality, quantity, standardization, social welfare, equity in the performance of waste management and other services i.e., water and sewerage and health then only final conclusions can be drawn and policy will be guided. There is urgent quest improvement in services delivery around world and Uganda is not an exceptional. If the model leads to achievement of economies of scale and improved efficiency, for which theories argued, then it is apparent that KCCA should strengthen the use of shared services.

Shared services have been founded on the basis of promoting efficiency and cost saving which limited its scope. Further research was necessary to widen the scope and also operationalize the components in order to discover other potentials of shared service. Further research is needed in different countries and regions using a big sample before conclusions are made especially in operational services like water and sewerage, waste management and health which the consumers are able to evaluate the performance.

\section{References}

Andrews, R., \& Boyne, G. A. (2009). Size, structure and administrative overheads: An empirical analysis of English local authorities. Urban Studies, 46(4), 739-759.

Andrews, R., \& Entwistle, T. (2010). Does Cross-Sectoral Partnership Deliver? An Empirical Exploration of Public Service Effectiveness, Efficiency, and Equity. Journal of Public Administration Research \& Theory, 20(3), 679-701. http://dx.doi.org/10.1093/jopart/mup045

Ashkenas, R., Ulrich, D., Jick, T., \& Kerr, S. (1995). The boundaryless organisation. Bassey-Joss, San Francisco, $C A$.

Boyne, G. A. (1996). Assessing party effects on local policies: a quarter century of progress or eternal recurrence? Political Studies, 44(2), 232-252.

Boyne, G. A. (2002). Public and private management: what's the difference? Journal of Management Studies, 39(1), 97-122.

Dollery, B., Byrnes, J., Dollery, B., \& Robotti, L. (2008). Structural reform in Australia. The theory and Practice of Local Government Reform, Edward Elgar, forthcoming.

Dollery, B., \& Crase, L. (2004). Is bigger local government better? An evaluation of the case for Australian municipal amalgamation programs. Urban Policy and Research, 22(3), 265-275. http://dx.doi.org/10.1080/0811114042000269290

Dollery, B., Crase, L., \& Johnson, A. (2006). Australian local government economics: UNSW Press.

Dollery, B., Grant, B., \& Akimov, A. (2010). A Typology of Shared Service Provision in Australian Local Government. Australian Geographer, 41(2), 217-231. http://dx.doi.org/10.1080/00049181003742310

Flynn, N. (1995). The future of public sector management: Are there some lessons from Europe? International Journal of Public Sector Management, 8(4), 59-67.

Goodnow, F. (1900). Policy and administration: New York: Macmillan.

Gulick, L. (1937). Lyndall Urwick, eds. 1937. Papers on the Science of Administration, 3-13.

Huckfeldt, R. R. (1995). Citizens, politics and social communication: Information and influence in an election campaign: Cambridge University Press.

Jackson, P. M. (1995). Measures for success in the public sector: CIPFA The Chartered Institute of Public Finance and Accountancy.

Jreisat, J. E. (1997). Public organization management: The development of theory and process. Quorum Books. 
Kuppusamy, S., Sidin, S., Sambasivan, M., \& Noor, Z. (2006). Performance Measurement for Local Authorities in Peninsular Malaysia. Service Delivery by Local Authorities: Issues and Challenges, 285-300.

Luthuli, T. (1999). Performance Based Pay System Efficiency and Effectiveness in the Public Service. Unpublished Masters Thesis, University of Witwatersrand.

McQuaid, R. W., \& Scherrer, W. (2010). Changing reasons for public-private partnerships (PPPs). Public Money \& Management, 30(1), 27-34.

Moharir, V. (1997). Policy Implementation: Operational Capability and Administrative Performance. Unpublished manuscript, Den Haag: Institutes of Social Studies..(1997b). Tutorials on Policy Implementation. Den Haag: Institute of Social Studies.

Osborne, S. P., \& Brown, K. (2005). Managing change and innovation in public service organizations (Vol. 1): Psychology Press.

Pike, T. (2012). An exploration of how shared corporate service operate and perform in English local government. Cardiff University.

Shah, A. (2003). Handbook of public sector performance review. World Bank.

Steiner, R. (2003). The causes, spread and effects of intermunicipal cooperation and municipal mergers in Switzerland. Public Management Review, 5(4), 551-571. http://dx.doi.org/10.1080/1471903032000178581

Sullivan, H., \& Skelcher, C. (2002). Working across boundaries: collaboration in public services: Palgrave.

Teisman, G. R., \& Klijn, E. H. (2002). Partnership arrangements: governmental rhetoric or governance scheme? Public administration review, 62(2), 197-205.

Thiel, S. v., \& Leeuw, F. L. (2002). The performance paradox in the public sector. Public performance and management review, 25(3), 267-281.

Waheed, A., Mansor, N., \& Ismail, N. A. (2011). Measuring Efficiency of Public Sector Organizations: A Case Study of Public Sector In-Service Training Institutes in Pakistan. Interdisciplinary Journal of Contemporary Research in Business, 2(10), 23-44.

Waste, C. (2011). Waste picking.

Wilson, W. (1987). The Study of administration: Academy of Political Science (US).

\title{
Appendix
}

\author{
Appendix A1 \\ UNIVERSITY MALAYA (MALAYSIA) \\ DEPARTMENT OF ADMINISTRATIVE STUDIES AND POLITICS \\ IMPROVING SERVICE DELIVERY: A CASE FOR SHARED SERVICES IN KAMPALA CAPITAL CITY \\ AUTHORITY \\ QUESTIONNAIRE FOR EMPLOYEES
}

\section{QUESTIONNAIRE ON SHARED SOLID WASTE AND GARBAGE COLLECTION IN KCCA.}

This questionnaire is prepared for assessing the respondents' views on solid waste management and garbage collection services in divisions of Kampala City Capital Authority. The information am seeking from you is purely for academic purposes, and it may also be used in improving solid waste collection and garbage management services in Kampala, and will be treated with outmost confidentiality. Your cooperation will be highly appreciated. Therefore, please feel free to answer the questions. Thank you.

Instructions on how to complete this questionnaire.

i. Please circle/indicate the correct option.

ii. Where your view/opinion is sought, just please write the required information in the space provided.

\section{SECTION A}

The purpose of this section is to capture the background information of the respondents in relation solid waste collection and garbage management services of KCCA. 


\subsection{RESPONDENTS PARTICULARS}

1.1 Division:

1.2 Date:

1.3 Gender
(a) Male
(b) Female

1.4 How many people are in your house?
(a) 1-2
(b) $3-5$
(c) $6-10$
(d) Above 10

1.5Age
(a) $20-29$
(b) $30-39$
(c) $40-49$
(d) $50-59$
(e) $60-69$
(f) $70+$

1.6 Highest Educational Qualification
(a) Primary
(b) Secondary
(c) Certificate
(d) Diploma
(e) Bachelor's Degree
(f) Masters
(g) $\mathrm{PhD}$

1.7 Are you employed?
(a) Yes
(b) No

1.8 If your answer in 1.7 above is Yes, indicate the organisation/Institution you work for

1.9 Designation/Job title Department/section

1.10 In which division of Kampala do you reside?
(a) Central
(b) Nakawa
(b) Lubaga
(d) Makindye
(e) Kawempe

1.11 For how long have you been residing in this division?
(a) 0-5 years
(b) 6-10 years
(c) 11-15 years
(d) $16-20$
(e) 21 and above

\section{SECTION B}

Objective of this section is to seek the respondents' view/opinion on solid waste management and garbage collection services in KCCA. Please circle the appropriate answer

2.1. How well do you understand the terms solid waste collection and garbage management?
(a) Very well
(b) Well
(c) Quite Well
(d) Somewhat well
(e) Fairly
(f) Somewhat poor $\quad$ (g) Quite poorly (h) poorly (i) Very poorly

If your answer in $\mathbf{2 . 1}$ above is from very well through to fairly, answer the following concerning the status of solid waste collection and garbage management in the divisions of KCCA.

2.2 Which among the following are the types of wastes generated in Kampala? (Select all that apply).
(a) Domestic waste
(b) Commercial waste
(c) Industrial waste
(d) Institutional waste
(e) Market waste
(f) Hospital waste

2.3 What are the most common ways for residents to dispose waste? (Select all that apply)
(a) Burn the waste
(b) Place in garbage containers (communal collection)
(c) Dump at the roadside
(d) Use formal collectors (contracted companies) (e) Use informal collectors (individual)

(f) Use NGOs $\quad$ (g) Others, please specify

2.4 Select among the following who are responsible for solid waste collection and garbage management in KCCA (Select all that apply)

(a) KCCA solid waste collection \& garbage management section (b) Private contracted garbage collectors

(c) Individual garbage collectors (scavengers)

(d)NGOs/CBOs (e)All of the above

2.5 Who among the following are the two common solid waste and garbage collectors in KCCA?

(a) KCCA solid waste collection \& garbage management section and Private contracted garbage collectors

(b) Private contracted garbage collectors and Individual garbage collectors (scavengers)

(c) Individual garbage collectors (scavengers) and NGOs/CBOs

(d) NGOs/CBOs and Private contracted garbage collectors

2.6 If the Private contracted garbage collectors is one of the common solid waste and garbage collectors, how many contractors are engaged by KCCA? 

(a) $1-10$
(b) $11-20$
(c) $21-30$
(d) $31-40$
(e) $41-50$
(f) 51-60
(g) Above 60

2.7 Select any safe waste disposal method used at KCCA among the following; (Select all that apply)
(a) Land filling
(b) Incineration (industrial burning)
(c) Composting (manure making)
(d) Recycling (e) All the above

2.8 Does KCCA have any of the following regulations and policies on solid waste collection and garbage management?

(a) Law on solid waste (b) Pollution control standards (c) Waste reduction, recycling and recovery (d) Solid waste collection and garbage management and pollution control (e) All the above

2.9 Which is the common means of waste collection used by KCCA? (Select all that apply)
(a) Waste collection \& transport vehicles
(b) Sealed compact vehicles
(c) Formal agents (hired) trucks
(d) Garbage collectors (individuals)
(e) All the above

2.10. Is sold waste collection a free service in KCCA to residents?
(a) Yes
(b) No
(c) Not sure

2.11. If your answer is No in 2.10 above, how much on average do one family spend per month on solid waste collection?
(a) $5000-10000 /-$
(b) $15000-20000 /-$
(c) 20000-30000/-
(d) More than 30,000/-

2.12. If your answer is Yes in 2.10 above, how are the garbage containers spaced?
(a) Less than 100 meters
(b) $200 \mathrm{~m}$ to $500 \mathrm{~m}$
(c) $500 \mathrm{~m}$ to $1 \mathrm{~km}$
(d) $1 \mathrm{~km}$ to $2 \mathrm{~km}$
(e) more than $2 \mathrm{~km}$
(f)Others please specify

2.13. To what extent do you agree that the landfill at Kitezi and waste collection transport vehicles cause additional pollution?
(a) Strongly agree
(b) Agree (c) Quite agree
(d) Somewhat agree
(e) Neutral
(f) Somewhat disagree
(h) Quite disagree
(i) Disagree
(j) Strongly disagree

2.14. Have you observed any good practices in KCCA on how they are managing solid waste like in collection, transportation, treatment and disposal?
(a) Yes
(b) No
(c) Not sure
2.15 If your answer is Yes in 2.14 above please state any of the good practices

2.16 Does KCCA have enough solid waste collection and management facilities \&equipments?
(a) Yes
(b) $\mathrm{No}$
(c) Not sure

2.17 If your answer is No in 2.16 above, what among the following do you think explains this? (Select all that apply)
(a) Lack of funds
(b) Lack of capacity
(c) Poor management
(d) No technical capacity
(e) Misuse of facilities and equipment (f) Corruption
(g) Lack of solid waste collection and garbage management policy

2.18 How is the solid waste collection and garbage management services funded? (Select all that apply)
a) KCCA revenue
(b) Government (c) Private sector
(d) International institutions e.g. WB, IMFetc
(e) All the above

2.19 In your opinion, do you think partnerships and shared solid waste collection and garbage management services among divisions can improve the delivery of this expensive service?
(a) Yes
(b) No
(c) Not sure

2.20. If your answer is Yes in 2.19 above, which among the following justifies partnerships and shared solid waste collection and garbage management services among divisions. (Select all that apply)
(a) Economies of scale
(b) Shared costs
(c) Reduced costs
(d) Improve service delivery (e) Improve on the equity
(f) Improve on the effectiveness
(g) Improve quality
(h) Improve standards
(i) Improve Social Welfare

2.21. In your opinion, what is the most positive aspect of partnering and sharing solid waste services among the following? (Select all that apply)
(a) Increase in the collection rate
(b) Proper transportation and treatment
(c) Sensitization waste program
(d) Increase Sanitation
(e) Reduce diarrhea

2.22 In your opinion, what is most serious problem encountered in partnering and sharing solid waste services among divisions from the list below? (Select all that apply) 

(a) Lack of coordination
(b) Untrusted partners
(c) Stake holder involvement
(d) Lack of shared vision
(e) Unequal distribution of resources
(h) Poor communication

2.23 Do you think that sharing of solid waste collection and garbage management services improves service delivery greatly in the divisions?
(a) Yes
(b) No
(c) Not sure

2.24 If your answer in 2.23 above is Yes, state the aspect in which it improves service delivery-

2.25. Do you agree that KCCA should encourage and support the shared service initiatives among the divisions?

(a)

Yes

(b) No

(c) Not sure

\section{SECTION C}

The purpose of this section is to investigate the respondents' views on service delivery in terms solid waste management and garbage collection under partnership and cooperation.

A number of statements regarding the residents' views towards service delivery under partnership in your division are presented below. Five possible reactions ranging from Strongly disagree (1) Disagree (2), Neutral (3), Agree (4) to Strongly agree (5) are listed under each statement. Please choose the alternative in which the answer that comes closest to the level of your satisfaction, and circle the appropriate choice.

Strongly agree (1), Agree (2), Neutral (3), Disagree (4), Strongly Disagree (5)

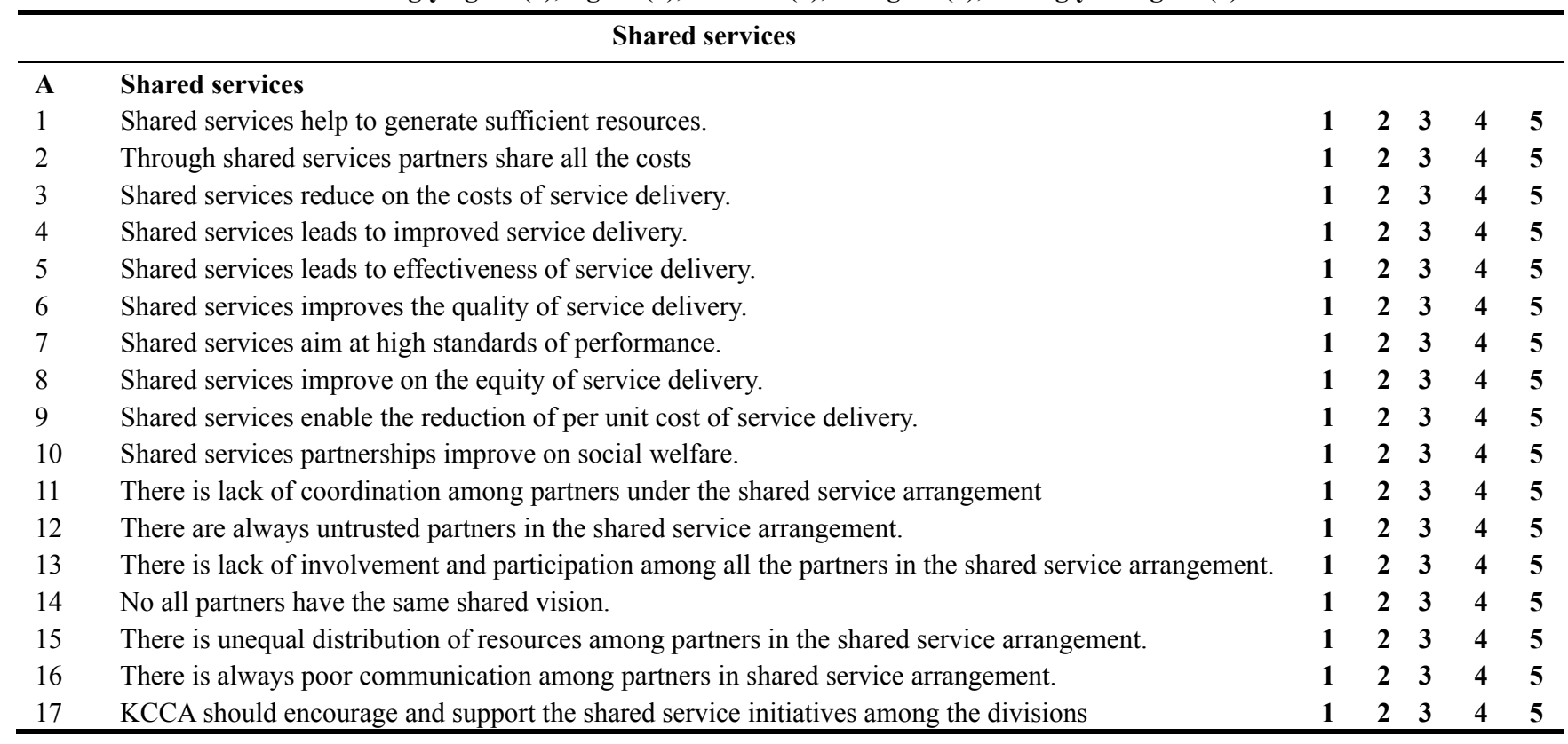

\section{SECTION D}

\section{SHARED SERVICES}

The objective of this section is to assess the respondents' views in relation to cost, quality and social welfare of Solid waste management and garbage collection of Kampala City Capital Authority.

Key: depending on the statement, the scale of change or achievement ranges can either be in agree, satisfied/satisfactory or acceptable for example agree range from Strongly disagree (1), disagree (2), somehow disagree (3), slightly disagree (4), neutral (5), slightly agree (6) somehow agree (7) quite agree (8), Agree (9) to Strongly agree (10). Answer the questions frankly by circling the correct answer in the box that is closest to your level of agreement with the statement /question.

\begin{tabular}{|c|c|c|c|c|c|c|c|c|c|c|c|}
\hline $\mathbf{S} /$ & Questions & & & ing & & & & & & & \\
\hline $\mathbf{A}$ & Cost Saving as a result of shared services in SWM & & & & & & & & & & \\
\hline 1 & $\begin{array}{l}\text { Partnerships (public-public) reduce costs as partners are united in common } \\
\text { goal and trust relationship }\end{array}$ & 1 & 2 & 3 & 4 & 5 & 6 & 7 & 8 & 9 & 10 \\
\hline
\end{tabular}


2 Do you agree that having a greater capacity to serve a large client base leads to reduction in the input prices

3 Do you agree that as a scale of production of any service increases, the proportion of cost falls

4 Do you agree that reducing duplication leads to lower costs

5 Sharing overhead costs among divisions leads to lowered costs of delivery services.

6 Administrative costs stem from the obligations to provide information

\begin{tabular}{llllllllll}
\hline 1 & 2 & 3 & 4 & 5 & 6 & 7 & 8 & 9 & 10
\end{tabular}

\begin{tabular}{lll}
\hline & 2 & 3
\end{tabular}

\begin{tabular}{llllllllll}
\hline 1 & 2 & 3 & 4 & 5 & 6 & 7 & 8 & 9 & 10 \\
\hline 1 & 2 & 3 & 4 & 5 & 6 & 7 & 8 & 9 & 10
\end{tabular}
which is set out in the legislation.

B Economies of scale

1 Do small jurisdictions capture citizens' true preferences and leaders can articulate their preferred level of service more precisely

2 Larger size division is preferred for realizing economies of scale in $\begin{array}{llllllllllllllllll} & \mathbf{2} & \mathbf{3} & \mathbf{4} & \mathbf{5} & \mathbf{6} & \mathbf{7} & \mathbf{8} & \mathbf{9} & \mathbf{1 0} & \end{array}$ production

3 Do you agree that fragmentation also limits local government's ability to gain economies of scale

4 Delivering services as an independent division is more costly than providing a service through partnership with other local councils

5 A large division possess ability to address externalities and diseconomies of scale by broadening consumption base.

6 Small divisions bring competition hence improved performance

7 Are managers freed from the day-to- day front office management and servicing clients to enable them concentrate on goals of the goals of the division?

8 Shared services may suffer diseconomies of scale and may not result into improved performance

C Efficiency

1 Divisions are exploiting the use of available resources

1 Resource recovery through waste processing

2 Recycling waste into local product

3 Resource recovery through sorting and recycling

4 Waste transformation i.e reduction of volume

5 Disposal on landfill. environmentally safe

\begin{tabular}{llllllllll}
\hline 1 & 2 & 3 & 4 & 5 & 6 & 7 & 8 & 9 & 10
\end{tabular}

\begin{tabular}{llllllllll}
\hline 1 & 2 & 3 & 4 & 5 & 6 & 7 & 8 & 9 & 10
\end{tabular}

\begin{tabular}{llllllllll}
\hline 1 & 2 & 3 & 4 & 5 & 6 & 7 & 8 & 9 & 10 \\
\hline 1 & 2 & 3 & 4 & 5 & 6 & 7 & 8 & 9 & 10 \\
\hline 1 & 2 & 3 & 4 & 5 & 6 & 7 & 8 & 9 & 10
\end{tabular}

\begin{tabular}{llllllllll}
\hline 1 & 2 & 3 & 4 & 5 & 6 & 7 & 8 & 9 & 10
\end{tabular}

Disposal on landfill. environmentally safe

2 Shared service partnerships are likely to reduce on the amount of time taken to deliver the services.

1 Reduced distance covered to dispose waste

2 Waste containers are fairly distributed

3 Improved mode of collection of waste

4 Involvement of many government agencies

5 Waste is collected in reasonable time periods

3 Shared service partnerships have enabled divisions to carry out their respective policies and plans in a more efficiently.

1 Achievement of integrated waste management planning

2 Implementation of solid waste ordinance 2000

3 The right of an individual to information on waste

$4 \quad$ Safety for the waste collectors and the residents

5 Effective monitoring of compliance with the national standards

\section{Effectiveness}

\begin{tabular}{llllllllll}
\hline 1 & 2 & 3 & 4 & 5 & 6 & 7 & 8 & 9 & 10 \\
\hline 1 & 2 & 3 & 4 & 5 & 6 & 7 & 8 & 9 & 10 \\
\hline 1 & 2 & 3 & 4 & 5 & 6 & 7 & 8 & 9 & 10 \\
\hline 1 & 2 & 3 & 4 & 5 & 6 & 7 & 8 & 9 & 10 \\
\hline 1 & 2 & 3 & 4 & 5 & 6 & 7 & 8 & 9 & 10 \\
\hline 1 & 2 & 3 & 4 & 5 & 6 & 7 & 8 & 9 & 10 \\
\hline
\end{tabular}

1 Public-public partnerships will be apparent in the effective measurement of performance 


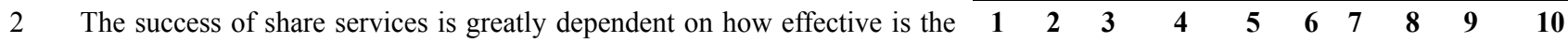
implementation process

3 Shared service arrangements will not gain from high levels supervision

4 Shared service arrangement will gain from high trust of the partners in the partnership

5 The partnership dissolves due to selfish interests of the agent and failure to deliver the services

6 Partnerships are also affected by too much control and supervision

7 Distrust can lead to dissolving of the partnership

\begin{tabular}{llllllllll}
\hline 1 & 2 & 3 & 4 & 5 & 6 & 7 & 8 & 9 & 10 \\
\hline 1 & 2 & 3 & 4 & 5 & 6 & 7 & 8 & 9 & 10
\end{tabular}

$\underline{\mathbf{E}}$

E Welfare

1 Low social class receive free garbage collection services in the different divisions

2 Welfare services are reliable in the divisions

3 There are strategies for social welfare in divisions

4 Welfare policy is meeting people's expectation

5 SWM activities under welfare programs satisfactory

6 Division are responding well towards welfare services

\begin{tabular}{llllllllll}
\hline 1 & 2 & 3 & 4 & 5 & 6 & 7 & 8 & 9 & 10 \\
\hline 1 & 2 & 3 & 4 & 5 & 6 & 7 & 8 & 9 & 10 \\
\hline 1 & 2 & 3 & 4 & 5 & 6 & 7 & 8 & 9 & 10 \\
\hline
\end{tabular}

\section{Quality}

1 There is improvement in technology use in the management of garbage

2 Waste treatment done frequently

3 Quality of tools and equipments used in garbage collection

Frequency in collection of garbage

4 Residents are satisfied with the achievements of solid waste collection and garbage management services in Kampala

5 Solid waste management and garbage collection interventions in $\begin{array}{ccccccccccccccc} & \mathbf{2} & \mathbf{3} & \mathbf{4} & \mathbf{5} & \mathbf{6} & \mathbf{7} & \mathbf{8} & \mathbf{9} & \mathbf{1 0}\end{array}$ improving service delivery are good

6 The status of the solid waste management and garbage collection services in KCCA is good

7 There is an effective solid waste generation policy in place.

8 Division residents' behavior toward waste generation change is good.

9 The solid waste and garbage collection management systems in place are environmentally friendly

\section{Quantity}

1 The number and spacing of solid waste collection containers is good

2 Solid waste management and garbage collection under partnerships increased the amount of equipments.

\section{Standardization}

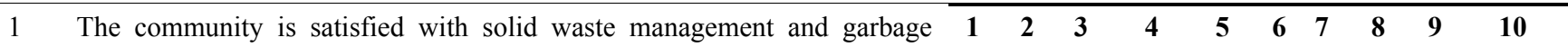
collection standards in KCCA.

2 The changes in the standards of waste management services in the $\begin{array}{lllllllllllllll} & \mathbf{1} & \mathbf{2} & \mathbf{3} & \mathbf{4} & \mathbf{5} & \mathbf{6} & \mathbf{7} & \mathbf{8} & \mathbf{9} & \mathbf{1 0}\end{array}$ divisions have improved like in technology.

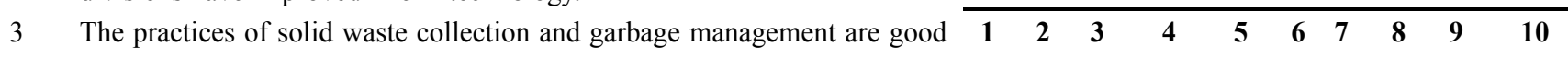
in the divisions after the partnership arrangement.

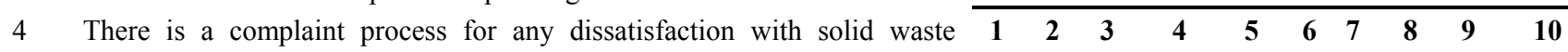
collection and garbage management in the division.

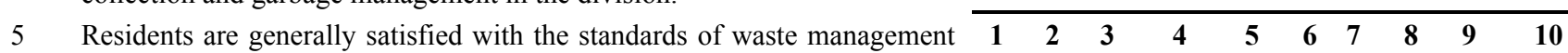
in divisions

\section{Equity}

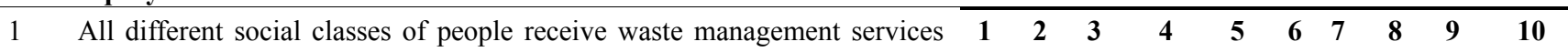
from the divisions

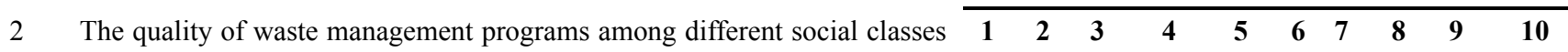
in the divisions is good. 


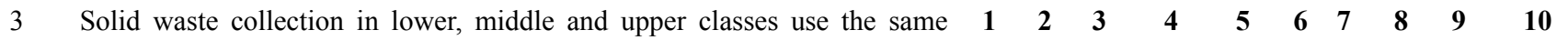
techniques in the division

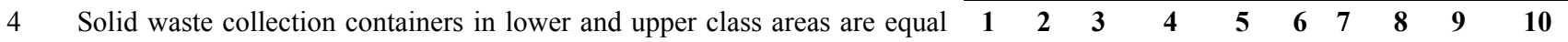
and same.

\section{End of the Questionnaire \\ Thank you \\ Appendix A2 (Omited) \\ UNIVERSITY MALAYA- MALAYSIA \\ DEPARTMENT OF ADMINISTRATIVE STUDIES AND POLITICS IMPROVING SERVICE DELIVERY: A CASE FOR SHARED SERVICES IN KCCA QUESTIONNAIRE FOR RESIDENTS}

QUESTIONNAIRE ON QUALTY OF SERVICE DELIVERED IN DIVISIONS BY KAMPALA CAPITAL CITY AUTHORITY IN TERMS OF SOLID WASTE MANAGEMENT SERVICES.

Appendix A3. Comparison of indicators among the five divisions of KCCA

\begin{tabular}{|l|l|l|l|l|l|}
\hline \multicolumn{2}{|l|}{ Solid waste budget for different divisions for 2012/43 KCCA } & & & \\
\hline & & & & \\
\hline Environmental Health Kawempe & Kampla central & Lubaga & Nakawa & Makindye \\
\hline $\begin{array}{l}\text { Improved Solid Waste } \\
\text { Management }\end{array}$ & $4,160,000$ & $4,160,000$ & $4,160,000$ & $4,160,000$ & $4,160,000$ \\
\hline $\begin{array}{l}\text { Sanitation drives and Home } \\
\text { Visiting in Villages }\end{array}$ & $6,060,000$ & $6,060,000$ & $6,060,000$ & $6,060,000$ & $6,060,000$ \\
\hline $\begin{array}{l}\text { Training of Zonal Environmental } \\
\text { Committees }\end{array}$ & $6,500,000$ & $6,500,000$ & $6,500,000$ & $6,500,000$ & $6,500,000$ \\
\hline $\begin{array}{l}\text { Solid Waste Management and } \\
\text { disposal }\end{array}$ & & & & & \\
\hline Clean City and reduced disease & $307,530,000$ & $402,500,000$ & $300,000,000$ & $288,000,000$ & $290,000,000$ \\
\hline Total & $324,250,000$ & $419,220,000$ & $316,720,000$ & $304,720,000$ & $306,720,000$ \\
\hline$\$$ & $\$ 120988.806$ & $\$ 156425.3731$ & $\$ 118179.1045$ & $\$ 113701.4925$ & $\$ 114447.7612$ \\
\hline
\end{tabular}

Appendix A4. Survey Data of Questionnaires

\begin{tabular}{|c|c|c|c|}
\hline /no & Questions & $\begin{array}{l}\text { No of } \\
\text { items }\end{array}$ & $\begin{array}{l}\text { Mean } \\
\text { score }\end{array}$ \\
\hline $\mathbf{A}$ & Cost Saving as a result of shared services in Solidwaste & & \\
\hline 1 & Partnerships (public-public) reduce costs & 1 & 4.71 \\
\hline 2 & Greater capacity & 1 & 6.65 \\
\hline 3 & Scale of production & 1 & 6.60 \\
\hline 4 & Reducing duplication & 1 & 8.07 \\
\hline 5 & Sharing overhead costs & 1 & 5.21 \\
\hline \multirow[t]{2}{*}{6} & Administrative costs & 1 & 7.12 \\
\hline & Total mean score & 6 & 6.393 \\
\hline B & Economies of scale & & \\
\hline 1 & Small jurisdictions & 1 & 2.20 \\
\hline 2 & Larger size division & 1 & 6.36 \\
\hline 3 & Fragmentation & 1 & 6.94 \\
\hline 4 & Independent division & 1 & 7.87 \\
\hline 5 & A large division possess ability & 1 & 5.73 \\
\hline
\end{tabular}




\begin{tabular}{|c|c|c|c|}
\hline 6 & Small divisions bring \& competition & 1 & 4.57 \\
\hline 7 & Freeing managers & 1 & 5.56 \\
\hline \multirow[t]{2}{*}{8} & Shared services \& diseconomies of scale & 1 & 6.57 \\
\hline & Total mean score & 8 & 5.725 \\
\hline $\mathbf{C}$ & Efficiency & & \\
\hline $\mathrm{c}$ & Divisions \& exploiting the resources & & \\
\hline 1 & Recycle through waste processing i.e. recovery of materials & 1 & 6.62 \\
\hline 2 & Recycling waste into local products & 1 & 6.69 \\
\hline 3 & Resource recovery through sorting & 1 & 7.90 \\
\hline 4 & Waste transformation and its impact availability & 1 & 5.97 \\
\hline \multirow[t]{2}{*}{5} & Environmentally safe and sustainable disposal in landfills. & 1 & 5.92 \\
\hline & & 5 & 6.62 \\
\hline $\mathrm{c}$ & Amount of time taken to deliver the services & & \\
\hline 6 & Improved mode of collection of waste & 1 & 7.2 \\
\hline 7 & Waste containers are fairly distributed & 1 & 6.16 \\
\hline 8 & Reduced distance covered to dispose waste & 1 & 7.1 \\
\hline 9 & Involvement of many agencies & 1 & 8.2 \\
\hline \multirow[t]{2}{*}{10} & Waste is collected in reasonable time periods & 1 & 8.04 \\
\hline & & 5 & 7.34 \\
\hline $\mathrm{c}$ & Shared service \&policies and plans & & \\
\hline 11 & Effective monitoring of compliance with the national standards through policy & 1 & 6.2 \\
\hline 12 & Achevement of intergrated waste management planning with other stake holders & 1 & 5.7 \\
\hline 13 & Implementation of solid waste ordinance 2000 to stop illegal dumping & 1 & 5.1 \\
\hline 14 & $\begin{array}{l}\text { The right of an individual to information on waste management like reduction in waste } \\
\text { generation }\end{array}$ & 1 & 4.9 \\
\hline \multirow[t]{3}{*}{15} & Safety for the waste collectors and the residents is taken into consideration & 1 & 5.3 \\
\hline & & 5 & 5.44 \\
\hline & Total mean score & 3 & 6.47 \\
\hline D & Effectiveness & & \\
\hline 1 & Public-public partnerships \& effective performance & 1 & 7.57 \\
\hline 2 & Success \& effective implementation process & 1 & 8.58 \\
\hline 3 & Shared service \& high levels supervision & 1 & 5.71 \\
\hline 4 & Shared service $\&$ high trust of the partners & 1 & 8.64 \\
\hline 5 & Shared services and selfish interests & 1 & 7.59 \\
\hline 6 & Partnerships \& control and supervision & 1 & 7.03 \\
\hline \multirow[t]{2}{*}{7} & Distrust \& dissolving of the partnership & 1 & 8.11 \\
\hline & Total mean score & 7 & 7.604 \\
\hline $\mathbf{E}$ & Welfare & & \\
\hline 1 & Low social class & 1 & 7.03 \\
\hline 2 & Reliability & 1 & 5.61 \\
\hline 3 & Strategies for social welfare & 1 & 5.07 \\
\hline 4 & Welfare policy & 1 & 3.62 \\
\hline 5 & SWM activities \&welfare programs & 1 & 5.26 \\
\hline \multirow[t]{7}{*}{6} & Responsiveness towards welfare services & 1 & 5.59 \\
\hline & Total mean score & 6 & 5.36 \\
\hline & Quantity & & \\
\hline & Number and spacing of SWM containers & 1 & 4.72 \\
\hline & SWM partnerships increased amount of equipments & 1 & 6.82 \\
\hline & Total mean score & 3 & 5.77 \\
\hline & Standardization & & \\
\hline
\end{tabular}




\begin{tabular}{|c|c|c|}
\hline Garbage collection standards & 1 & 5.75 \\
\hline Changes in the standards & 1 & 5.05 \\
\hline The practices of SWM & 1 & 5.39 \\
\hline Complaint process & 1 & 4.40 \\
\hline Residents' satisfaction & 1 & 5.53 \\
\hline Total mean score & 5 & 5.23 \\
\hline Equity & & \\
\hline Social classes & 1 & 6.95 \\
\hline Quality of waste programs \& social classes & 1 & 5.79 \\
\hline Same techniques for different classes & 1 & 5.74 \\
\hline SW containers equal and same. & 1 & 6.04 \\
\hline Total mean score & 4 & 6.13 \\
\hline
\end{tabular}

